\title{
Erratum to: 'Antitumor and antimetastatic activities of chloroform extract of medicinal mushroom Cordyceps taii in mouse models'
}

\author{
Ru-Ming Liu' ${ }^{1}$ Xiao-Jie Zhang ${ }^{1}$, Gui-You Liang ${ }^{1}$, Yong-Fu Yang ${ }^{2}$, Jian-Jiang Zhong ${ }^{3^{*+}}$ and Jian-Hui Xiao ${ }^{1^{*+}}$
}

Unfortunately, the original version of this article [1] contained an error. Two of the affiliations were incorrect. The correct affiliations can be found below.

Correspondence: jhxiao@yahoo.com; jjzhong@sjtu.edu.cn

${ }^{1}$ Guizhou Center for Translational Medicine \& Laboratory of Cell Engineering, Affiliated Hospital of Zunyi Medical University, Zunyi 563000, China.

${ }^{3}$ State Key Laboratory of Microbial Metabolism, Joint International Research Laboratory of Metabolic \& Developmental Sciences, and School of Life Sciences \& Biotechnology, Shanghai Jiao Tong University, Shanghai 200240, China.

${ }^{\dagger}$ Both authors contributed equally to this work.

\begin{abstract}
Author details
${ }^{1}$ Guizhou Center for Translational Medicine \& Laboratory of Cell Engineering, Affiliated Hospital of Zunyi Medical University, Zunyi 563000, China. 2Department of Pathology, Affiliated Hospital of Zunyi Medical University, Zunyi 563000, China. ${ }^{3}$ State Key Laboratory of Microbial Metabolism, Joint International Research Laboratory of Metabolic \& Developmental Sciences, and School of Life Sciences \& Biotechnology, Shanghai Jiao Tong University, Shanghai 200240, China
\end{abstract}

Received: 29 July 2015 Accepted: 29 July 2015

Published online: 18 August 2015

\section{Reference}

1. Liu R-M, Zhang X-J, Liang G-Y, Yang Y-F, Zhong J-J, Xiao J-H. Antitumor and antimetastatic activities of chloroform extract of medicinal mushroom Cordyceps taii in mouse models. BMC Compl Alternative Med. 2015; 15 (216): doi:10.1186/s12906-015-0762-9.

\footnotetext{
* Correspondence: jizhong@sjtu.edu.cn; jhxiao@yahoo.com

${ }^{\dagger}$ Equal contributors

${ }^{3}$ State Key Laboratory of Microbial Metabolism, Joint International Research Laboratory of Metabolic \& Developmental Sciences, and School of Life Sciences \& Biotechnology, Shanghai Jiao Tong University, Shanghai 200240, China

${ }^{1}$ Guizhou Center for Translational Medicine \& Laboratory of Cell Engineering, Affiliated Hospital of Zunyi Medical University, Zunyi 563000, China Full list of author information is available at the end of the article
}

\section{Submit your next manuscript to BioMed Central and take full advantage of:}

- Convenient online submission

- Thorough peer review

- No space constraints or color figure charges

- Immediate publication on acceptance

- Inclusion in PubMed, CAS, Scopus and Google Scholar

- Research which is freely available for redistribution
C Biomed Central (c) 2015 Liu et al. Open Access This article is distributed under the terms of the Creative Commons Attribution 4.0 International License (http://creativecommons.org/licenses/by/4.0/), which permits unrestricted use, distribution, and reproduction in any medium, provided you give appropriate credit to the original author(s) and the source, provide a link to the Creative Commons license, and indicate if changes were made. The Creative Commons Public Domain Dedication waiver (http://creativecommons.org/publicdomain/zero/1.0/) applies to the data made available in this article, unless otherwise stated. 